\title{
THE NOTWITHSTANDING TABOO
}

\author{
Richard McAdam, Dalhousie University \\ Department of Political Science, M.A. Candidate
}

The existence of the notwithstanding clause in 5.33 of the Canadian Charter of Rights and Freedoms allows the federal and provincial governments to overrule the fundamental freedoms and legal and equality rights of Canadian citizens. Built into the override is a sunset clause, requiring governments to renew any legislation using s.33 every five years. The government is also required to state explicitly which Charter rights are being overridden, though in the limited extent to which the override has been used, the invocation of s.33 has always been vague and proclaims to operate notwithstanding all of the relevant sections of the Charter to which the override applies, sections 2 (fundamental freedoms) and 7 to 15 (legal and equality rights).

The constitutional entrenchment of rights for Canadians enhanced the institutional heritage of protecting rights through the rule of law, responsible government, and parliamentary sovereignty by adding judicial review to the Charter process. ${ }^{1}$ Through the notwithstanding clause, a balance was struck between Parliament's supremacy and the courts, limiting the extent to which "the Supreme Court of Canada's decisions must be obeyed by the legislatures"2 on issues subject to Charter review. This presents a two-track problem heretofore unseen in Canada: a government can either pass legislation that uses the override, explicitly violating rights; or, it can pass legislation that does not invoke s.33 but, upon judicial review, is found to transgress rights and is struck down by the courts. As Hogg notes, the Supreme Court no longer has the final word in cases involving ss.2 and 7-15, leaving the government to invoke the notwithstanding and end the debate. ${ }^{3}$

Yet in spite of the compromise aimed at strengthening the government's legislative supremacy over the judiciary, it has been very reluctant to invoke s.33 to override the rights of Canadians. In fact, the federal government has never used the notwithstanding clause in the Charter era, ${ }^{4}$ and the provinces, other than Quebec, have only used it very sparingly. Why, having based the acceptability of the entire constitutional package on the insertion of the override clause, have the federal and provincial governments been loath to use it? The answer lies in the emergence of the taboo surrounding its usage. 
The objective of this paper will be to demonstrate the existence and force of the notwithstanding taboo, a barrier to its invocation that stems from a combination of normative opposition to violating Canadians’ rights and political-electoral interests. First, I construct the notion of taboo as functionally distinct from a convention or a norm, which renders the idea of utilizing the notwithstanding clause to the margins of their legislative strategy. Any invocation of s.33 would both violate the principle of respecting Charter rights and would cause political backlash that could significantly affect the governing party's electoral fortunes. Second, I examine the evolution of this taboo surrounding the override clause, from its initial inception in John Diefenbaker's Bill of Rights, which entered into force in 1960, through its modification and expansion in the Charter of Rights up to the present in order to determine the extent to which its demonization will restrict its usage in the future. It must be recalled that using the override clause now would break a pattern of 25 years of non-usage and holding the Charter of Rights sacrosanct at the federal level, which supports the argument that suggests that as time goes on and the continued practice of non-use endures, the likelihood of it being used continually decreases. ${ }^{5}$ The previous rights regime in Canada, governed by the Bill of Rights, endured for a decade before being temporarily suspended by Trudeau during the FLQ crisis and subsequently enduring a restriction on the freedom of association clause. For a rights regime that only enjoyed statutory status, this in itself is commendable and demonstrative of the strong tradition in Canadian government to follow the principles of the rule of law and responsible government. With the Charter of Rights entrenched in the Constitution, it holds even higher status in the minds of Canadians. Third, the paper examines a number of "near-miss" cases in which Canada’s prime ministers in the Charter era encountered situations in which using the notwithstanding clause was broached as a policy avenue to resolve policy problems. Brian Mulroney, Jean Chrétien, Paul Martin, and Stephen Harper have all had encounters with s.33, and all of them ultimately rejected its usage, either out of principle or political pragmatism. Finally, with the one aforementioned exception, the federal government has unfailingly defended and upheld the rights of Canadians for almost half a century. Is this reason to believe that the trend will continue? This question will be evaluated in the face of potential challenges to the taboo. 


\section{I: What Is a Taboo?}

In liberal democracies today there are only a small number of actions or policies that are considered "off-limits" for politicians and heads of government. They are generally affiliated with conducting foreign policy. The most prominent taboo in international relations involves using weapons of mass destruction, particularly nuclear weapons, as a legitimate instrument of warfare. The emphasis on "the bomb" does not suggest that utilizing chemical or biological weapons is less repugnant or deserving of less opprobrium by the "international community" in the event of their usage. What makes nuclear weapons stand out as a separate entity altogether is their sheer destructiveness and ability to instantly destroy thousands of lives and devastate the collective psychology of a state's civilian population. It is for that reason a "normative prohibition on nuclear use has developed in the global system, which, although not (yet) a fully robust norm, has stigmatized nuclear weapons as unacceptable weapons of mass destruction.”6 That factor, like other highly credible theories of deterrence and mutually assured destruction, plays a central role in considerations for avoiding the usage of weapons that could end a war within minutes. In the forum of public opinion, domestic and global, "nuke 'em," though a popular Hollywood film solution, is unacceptable as a legitimate policy option, all the more so for democratically accountable governments.

Nuclear weapons and Canada's notwithstanding clause are not moral equivalents. Yet the past quarter-century, and indeed the past half-century if we acknowledge the override clause contained in the original Bill of Rights, has demonstrated that the invocation of s.33 would represent a political atomic bomb being dropped on the rights of Canadians. ${ }^{7}$ Peter Hogg, Canada's foremost constitutional expert, predicted in 1982 that "the exercise of the [override] power would normally attract such political opposition that it would be rarely invoked; but the means of escape from the Charter is there without the necessity of a constitutional amendment." To one Charter analyst, that very fact "is an invitation to its use," suggesting that "Parliament and the legislatures might be prone to accept this invitation." "Yet Parliament has not used its overriding power, and the legislatures have not done so with much enthusiasm as might have been expected by those who had predicted a "checkerboard" of rights in Canada.

In order to achieve the level of "taboo," as opposed to convention (i.e. disallowance) or even a norm (i.e. a government adhering the will of Parliament and resigning after losing a vote of confidence), there are many factors which must come into coalition. Taboos are a certain, 
elevated, type of norm, which can be defined as a "shared expectation of behaviour, a standard of right and wrong," 10 but they go further than norms in the extent to which they provoke opposition from both the public and its policy practitioners. Rather than being simply decisions or actions that political leaders do not undertake, taboos are policy choices they absolutely should not undertake because they are seen to lack legitimacy.

What are the criteria that raise norms to taboos? First, there must be a strong opposition from the public to a certain policy. This is a voice which must be expressed in unqualified terms. It is not enough for the populace to express potential dissatisfaction regarding a policy outcome; citizens must reject the outcome as being illegitimate and express that pursuing that outcome will have dire consequences. This public reaction must profoundly affect the decision-making choices pursued by policy-makers, who will, if the public's discourse on a notwithstanding taboo is sufficiently compelling, pursue what can be labeled "dilemmas of common aversion," which "exist when all actors share a concern to avoid a particular outcome."11 In the example of the emerging notwithstanding taboo, no political party, particularly at the federal level where the taboo is strongest, actively desires to use the notwithstanding clause because they believe that it will have major ramifications for their electoral hopes. There is an emerging consensus between both governing and governed regarding its usage: citizens largely oppose using the notwithstanding clause for any reason, and the Prime Minister and the Leader of the Opposition are both on record stating that they would not use the override. ${ }^{12}$ Beyond the political-electoral concerns, many prominent Canadian politicians have major reservations about limiting rights for any reason, no matter how "politically popular" or "justifiable" such an action may seem at the time. The idea that "rights are rights are rights" is a lofty standard held by many Canadians, and any infringement upon Charter rights would be viewed as a dangerous outcome because of potential future implications.

The power of a normative argument in the question of limiting or revoking rights thus takes shape in the "slippery slope" context: once the Pandora's Box is opened, what is to prevent further exercises of override authority to systematically deprive Canadians of their rights? This notion arouses great concern among Canadians because of our fundamental attachment to rights as something intrinsic to our "expressions of our moral identity as a people" and which "give legal meaning to the values we care most about—dignity, equality, and respect." 13 Because Canadians hold rights so dearly, an appreciation for what we have and what we see when we 
look at systemic human rights abuses in non-democratic states, we stand against any government that would infringe upon these rights. The onset of the Charter era fundamentally changed the way in which Canadians view rights, and Trudeau was exactly correct in his classification of the Charter as both a "sword and a shield on behalf of the average Canadian." ${ }^{14}$ A shield, once chipped by an initial blow, becomes weakened, and thus once the initial usage of the notwithstanding clause occurs, there will, the pessimists argue, be less disinclination to use the override in the future. The "morality of the ballot box" holds considerable power over governments, and this is but the initial deterrent factor for politicians even considering opening the Pandora's Box and going down the slippery slope. Though I do not fully agree with Monahan's assessment that the notwithstanding clause "is obsolete in English Canada,"15 the extent to which it has been delegitimized at the federal level has rendered it essentially off-limits in Ottawa. The notwithstanding taboo remains less powerful among provinces; though they have not used it for over six years, that it has been used at all indicates greater boldness in defying the preference of the electorate.

The notwithstanding taboo has not prevented politicization of s.33 in recent years. The same-sex marriage debate was a powder-keg for all political parties for its impact on social norms, traditions, religious rights, and equality rights. ${ }^{16}$ The culmination of this series of events occurred in January 2006 when then-Prime Minister Paul Martin vowed that the first act of a reelected Liberal government would be to strip the federal government of its ability to invoke the notwithstanding clause.

The override power has thus become a political instrument used to instill in voters a fear of political parties who would suggest its usage. This begs the question: when Martin made his pledge, was it done because he genuinely believed that under no circumstances was there a compelling argument for usage of the override? Or was it done because he had planted the seed in peoples' minds that Stephen Harper would use s.33 to deprive same-sex couples of their newly-acquired rights, breaking the notwithstanding taboo and thus potentially accepting future "invitations" to exercise that power? Martin's own public record on the same-sex marriage issue suggests the latter. He had once speculated that in passing Bill C-38 he would use the notwithstanding clause to protect churches and religious associations from performing same-sex marriages against their religious beliefs, stating, "I would look at it if it was a question of affirming a religious right." ${ }^{, 17}$ The government’s position had solidified by early 2005. Justice 
Minister Irwin Cotler, himself a constitutional expert on the Charter and its limits in protecting rights under s.2 (which includes, inter alia, freedom of religion), ${ }^{18}$ stated, "Rights are rights are rights," and any usage of s.33 "would really be an acknowledgment by the government that it is violating rights." ${ }^{19}$ This paper will return to the debate in its discussion of future challenges to the notwithstanding taboo, but it is easy to see the effect this issue has already had, causing both proponents and opponents to demand the government invoke s.33 to protect rights, religious or equality, from being infringed by Bill C-38.

The ultimate guarantor of the notwithstanding taboo is the trust and faith that Canadians place in their government to not abridge their rights. Thus far, they have earned that trust, and I concur with the assessment that "until the notwithstanding clause is abused 'by some thwarting of the legitimate aspirations of a truly dispossessed or marginalized group in our society,"” Canada's leaders do deserve the benefit of the doubt that they will uphold the notwithstanding taboo. ${ }^{20}$ Following the 2006 election campaign, during which the Martin Liberals often charged that the Conservatives would limit Charter rights via the notwithstanding clause, Stephen Harper spoke of the trust which the voters had placed in his party and in his pledge to avoid the use of

s.33 to overturn same-sex marriage rights. ${ }^{21}$ Harper has thus come to understand the power of the notwithstanding taboo. The situation he faces as Prime Minister is different than that as Leader of the Opposition. When in government, policy-makers have greater authority and means to enact legislation; the message Harper received from the voters during the campaign was that rights are not to be bandied about as bartering tools. He now has a dilemma of aversion, and his past statements regarding the use of the notwithstanding clause may come into play in a future election regardless of his conduct in his first term.

\section{II: The Bill of Rights Regime}

A legitimate examination of the doctrines governing Canadians' rights and freedoms must begin with the long-overlooked and ill-appreciated Bill of Rights that was passed by John Diefenbaker's Conservative government in 1958 and entered into force in 1960. It must be remembered that until Diefenbaker, though Canada was a signatory to the United Nations' Universal Declaration of Human Rights in 1948, there existed no domestic legal code to protect the fundamental rights of Canadians. This was apparently not a problematic issue for citizens 
until World War II brought to light the potential dangers of the absence of legislation protecting individual liberties from the state. ${ }^{22}$

In 1958, the Diefenbaker government enacted its Bill C-44, An Act for the Recognition and Protection of Human Rights and Fundamental Freedoms. ${ }^{23}$ A simple federal statute, the Bill of Rights contained many of the provisions existing in the current Charter regime, but it lacked constitutional entrenchment and its authority only extended to the federal government, which theoretically could amend or repeal its provisions in future sessions of Parliament. Although the Bill of Rights contained a provision guaranteeing "enjoyment of property, and the right not to be deprived thereof," 24 the lack of which in the Charter has been identified by Stephen Harper as a deficiency in Canada's current rights regime and something he would seek to redress in the event of a reopened constitutional debate, ${ }^{25}$ property rights fall under provincial jurisdiction and thus could not be enforced under the Bill of Rights.

Yet many of the criticisms of the Bill of Rights are simplistic and overlook its actual historical record. In spite of its legal weaknesses and its own notwithstanding clause, the legislation was rarely tampered or challenged. It took a full decade after coming into force for a Bill of Rights case to reach Canada's Supreme Court. In that first case, $R$. v. Drybones (1969), the Court ruled to enforce a provision of the Bill of Rights against a section of the Indian Act. The equality rights of Aboriginals-as-Canadians were upheld in opposition of the Indian Act's provision that it is a crime for Aboriginals to be intoxicated "anywhere off a reserve.”26 Because it is not illegal for non-Aboriginal Canadians to be intoxicated in most areas, the Indian Act was thus found to be discriminatory and the Court ruled appropriately. As such, the casual dismissal of the Bill of Rights today is inconsistent with its legal achievements affirming Canadians' rights.

At the political level, the Bill of Rights was also accorded a measure of respect and deference. For the course of its existence politicians dared not suggest weakening or repealing its provisions else they be attached to the label of disregarding the rights of Canadians. Diefenbaker's Conservatives, the same party that introduced Canada's “New Deal” legislation during the Great Depression, highlight the unique character of Canadian conservatism, which expresses “an element of 'tory democracy' - the paternalistic concern for the condition of the people.”27 This is distinct from American conservatism, which desires to preserve the bourgeois liberal traditions such as individual liberty and democratic capitalism; whereas the American "Republican is always a liberal," a Canadian Conservative "may be at one moment a liberal, at 
the next moment a tory, and is usually something of both.”28 Thus, having introduced the Bill of Rights and staked out turf in a previously tabula rasa territory domestically, ${ }^{29}$ the Tories would subsequently portray themselves as the champions of rights in Canada. Though Diefenbaker despaired at court judgments of the 1970s indicating a "desire to chisel away at some of the freedoms” prescribed by the Bill, he remained proud of his accomplishment. ${ }^{30}$

Yet for the majority of the Bill of Rights' existence as Canada's preeminent rights document, Canada was governed by Liberals. Lester Pearson defeated Diefenbaker in 1963 and was succeeded by Pierre Trudeau in 1968. Trudeau in particular viewed individual rights as of great importance, yet it was under his leadership that the Bill of Rights would face its greatest challenge. First, during the FLQ crisis, the Bill was temporarily suspended, and the police were given tremendous emergency powers to deal with the terrorists. Trudeau's statement of 16 October 1970 indicates his reluctance in suspending rights even in the wake of a genuine national security threat:

These are strong powers and I find them as distasteful as I am sure you do. They are necessary, however, to permit the policy to deal with persons who advocate or promote the violent overthrow of our democratic system. In short, I assure you that the Government recognizes its grave responsibilities in interfering in certain cases with civil liberties, and that it remains answerable to the people of Canada for its actions. The government will revoke this proclamation as soon as possible. ${ }^{31}$

Technically, Trudeau's invocation of the War Measures Act did not constitute a breach of the notwithstanding taboo. The Bill of Rights, in s.6, stated that "any action taken under the War Measures Act 'shall be deemed not to be an abrogation, abridgement or infringement of any right or freedom," contained therein. ${ }^{32}$ It was the subsequent passage of the Public Order (Temporary Measures) Act, which declared the FLQ an illegal organization, under s.3, and any person who, inter alia:

a. is or professes to be a member of the unlawful association;

b. acts or professes to act as an officer of the unlawful association

to be "guilty of an indictable offence and liable to imprisonment. ${ }^{33}$ The Act made explicit reference, in s.12, to its operation notwithstanding the Bill of Rights. The "freedom of association" clause was thus limited for the six-month duration of the Act's operation, marking the only occasion that Canada's federal government has deviated from the normative principle of non-usage of a notwithstanding clause. 
An outcome of the usage of the notwithstanding clause in this instance does deserve mention for potential future cases under the current Charter regime. In a time of national security, Canadians’ rights were restricted and “no civil liberties arguments were raised... [and] civil libertarians, and defence lawyers amongst them, had 'estopped' [sic] themselves from raising these issues.”34 The implications for rights in the event of a terrorist attack or other national security emergency could be severe, and it will fall upon Canadians to enforce the notwithstanding taboo to prevent the government from engaging in "lesser evil" tactics such as those undertaken by Trudeau in the name of security.

\section{III: Birth of the Charter Regime}

The Charter of Rights and Freedoms represents one of Canada's most significant political and constitutional achievements. It is a document that citizens can look to with pride and honour as a symbol of Canada's liberal democracy and respect for the rule of law. As earlier stated, it fundamentally altered Canadians' perception of rights to a level unseen during the previous rights regime. For Trudeau and Jean Chrétien, the Prime Minister and the Minister of Justice at the time and the central actors for the federal government, the inclusion of an entrenched Charter in the Constitution represented the culmination of a process both had long advocated since their election to Parliament in the 1960s. Both were elected in the era of the Bill of Rights, and neither felt that it went far enough in guaranteeing Canadians' liberties. The Charter solved that dilemma.

The achievement was not an unqualified success. Indeed, the compromise required to get provincial governments on board-the inclusion of the override provision via s.33 of the Charter-was a humiliation for Trudeau. When asked if he had traded away rights to make a deal, at the expense of a potential "checkerboard" Canada in which some provinces respected rights but others did not, Trudeau could only respond, "Yes.”35 Moreover, the first ministers' negotiations were concluded without the collaboration of Quebec. Its government reacted to the snub by opting out of the Charter "to the maximum extent possible ... by introducing a 'notwithstanding clause' into each of its existing” and subsequent statutes in a demonstration of

the political illegitimacy of the Constitution in the province. ${ }^{36}$ While the rest of the country celebrated, Quebec's flags flew at half-mast. The problems involving Quebec separatism and its view of the legitimacy of Canada post-1982 are numerous and beyond the scope of this paper; 
however, the story of Quebec and the Charter serves as an excellent analogy to the concept of rights in Canada. Like consent for the Constitution, Charter freedoms are not absolute and unequivocal.

From an electoral standpoint, a government that takes rights away from citizens risks jeopardizing its future success. Rights and liberties are essential tenets in liberal democracies such as Canada, and governments seeking to act, even in times of crisis, are playing with fire when they broach the subject of curtailing rights as a "lesser evil" in the face of a national security emergency. As Michael Ignatieff correctly states, "A government seeking to respond to an attack or an expected danger is required to present the case for extraordinary measures to a legislature, to argue for them with reasons that might convince a reasonable person, and to alter the measures in the face of criticism. ${ }^{37}$ The government will then be answerable for such measures at the time of the next election, and questions will arise whether suspending or overriding rights was justified.

\section{IV: The Notwithstanding Taboo in the Charter Era}

The Charter era of rights in Canada is now in its twenty-fifth year; it is a testament to the power of the notwithstanding taboo that "seven of the ten provinces and two of the three territories have never used the power of override; nor has the federal Parliament." ${ }^{38}$ As the following discussion demonstrates, there have been debates in which political actors have contemplated the use of s.33 but avoided its usage, deterred by various ethical and electoral factors. Yet even in those isolated cases outside of Quebec where the override has been invoked, it has ultimately re-enforced the taboo.

When the first ministers came to agree on the Charter of Rights and Freedoms, many actors moved to immediately establish their position regarding the notwithstanding clause. To provide themselves political cover in the wake of their compromise on the Charter, Trudeau and Chrétien both put up a parliamentary supremacy-based defence of the override clause, the former asserting, "I don't fear the notwithstanding clause very much," while Chrétien advanced the notion that the role of s.33 was a tool to provide "flexibility" to legislatures in having the final word on "important matters of public policy."39 Though the federal government's principal actors portrayed the override clause as a balance-of-power instrument, many analysts have disagreed with this initial conception, and I certainly concur that this defence is merely a means 
of deflecting discussion away from the significance of their compromise to the provinces that helped bring the Charter into existence. The critics focus on the compromise with the provinces in order to gain consensus on the constitutional package as the true purpose behind s.33's existence. Manitoba, Quebec, and Saskatchewan had all outright opposed entrenchment of the Charter, while other provinces had expressed varying degrees of support upon certain conditions and concessions. ${ }^{40}$ Thus the notwithstanding clause "had more to do with the raw politics of bargaining and chance phone calls late at night than with reasoned debate about what might constitute a rational compromise between democracy and constitutional law." ${ }^{41}$ Taken in that light, there is little doubt as to the reasons Trudeau avoided discussion regarding potential applications of s.33 to future legislation, even in the anticipatory sense to ward off "possible negative judicial intervention" ${ }^{, 42}$ that would become its norm in future years. His statement about not fearing the override clause was not based on using it without repercussions, but rather on the secure knowledge that he would not be utilizing it during his tenure.

\section{V: The Taboo in Full Force: Ottawa and s.33}

The strongest evidence in support of the existence of a normative basis for the non-use of the notwithstanding clause is the fact that it has never been utilized by the federal government. Moreover, there exists only scant evidence that Ottawa has ever even considered using the override power to limit or restrict Charter freedoms. Because the federal government is perceived to be a unifying actor responsible for the ominous task of shaping "public demands and expectations" and respecting all Canadians as "individuals endowed with common rights," ${ }^{43}$ it sets the national standard by which, it is hoped, all other governments will behave regarding Charter rights. Were Ottawa to invoke s.33, it could conceivably induce the provinces to do likewise. For that reason, among others, the federal government has exercised a self-imposed ban on using the override power.

When Paul Martin stated that his first act if re-elected in the 2006 federal election would be to pass legislation to strip the federal government's power to use the override, some viewed his statement as a means of putting into force what has been a long-standing convention. However, many critics saw Martin's concept as short-sighted and unnecessarily tipping the balance of power in favour of the unelected judiciary. The Supreme Court decision in Multani v. Commission scolaire Marguerite-Bourgeoys (2006), which held that the Sikh religious practice 
of wearing the kirpan was violated by a school board's decision to restrict the custom, is a potential case for the use of the override clause. The decision overturned the Quebec Court of Appeals' ruling that the ban was justified on the grounds of “reasonable limits” in ensuring public safety. ${ }^{44}$ Had Martin won re-election, the idea of using s.33 would have been off the table for a federal ban on wearing the kirpan in public places such as schools. ${ }^{45}$ In her statement representing the majority opinion, Justice Charron wrote:

A total prohibition against wearing a kirpan to school undermines the value of this religious symbol and sends students the message that some religious practices do not merit the same protection as others...It is incumbent on the schools to discharge their obligations to instill in their students this value that is at the very foundation of our democracy. ${ }^{46}$

As such, the Harper government avoided action-indeed, even comment-on this issue to redress parental concerns that some students at school are carrying what can be considered a weapon, aware it would have to use the override to curtail a religious freedom. ${ }^{47}$ For a government that in opposition fought in the name of religious freedoms against same-sex marriage, this would have been a decidedly awkward situation.

Should the Harper government continue to avoid discussion of invoking s.33 to overturn a Court decision, it will follow in a lengthy tradition of prime ministers who have resisted the temptation of override. Indeed, nearly every Canadian leader during the Charter era has encountered a situation in which they encountered extra-parliamentary pressures to break tradition and invoke s.33 on a pressing matter. As earlier discussed, Trudeau was superbly confident that he would not be compelled to use the override, and his retirement from politics in 1984 meant that he was Prime Minister for only a very short time after the Charter came into force. John Turner and Kim Campbell's short tenures as place-holders following the departures of Trudeau and Brian Mulroney, respectively, essentially excluded them from any major decisions about the notwithstanding clause, ${ }^{48}$ and it is still early in Stephen Harper's rule to gauge what he will do. That leaves Mulroney, Jean Chrétien, and Paul Martin as the three prime ministers who have encountered the notwithstanding clause at length during their tenures.

Brian Mulroney's position on the notwithstanding clause is very clear. He had contempt for Trudeau's compromise, stating in a House of Commons speech, "Never before in our history has a Prime Minister of Canada made a concession of such magnitude and importance. Never before has the surrender of rights been so total and abject." 49 Mulroney thus had a normative 
opposition to the very existence of s.33, rendering the likelihood of its usage under his stewardship out of the question. His discussion of s.33 in the context of the Meech Lake Accord was the Quebec's acceptance of the Constitution would relegate the idea of "opting out of Canada" via s.33 to illegitimate status in the province, much as it had become in the rest of Canada. Mandel has noted that Mulroney’s discussion of the notwithstanding clause served to demonstrate "how potent a symbol of evil" it was in English Canada. 50

At the same time as the Meech debate was taking place, a political firestorm erupted following the Supreme Court's verdict in the Morgentaler (1988) case to strike down the federal government's abortion legislation on grounds under s.7 of the Charter ("life, liberty, and the security of the person”). The debate between conservatives, who hold the view that a fetus is a person who enjoys the "right to life," and liberals, who contend that so does a mother with the right to freedom of action, was furious. It engaged Parliament to draft new legislation that provided some restriction while still accounting for s.7 rights. A series of bills were defeated in the House of Commons, ultimately resulting in Mulroney abandoning the issue to tackle higherpriority items on his agenda.

In none of those legislative efforts, including the most restrictive of the proposed billsBill C-43, which would have sentenced "doctors to two years in jail for performing abortions where a woman's health is not at risk" using s.33, though external pressures abounded. Mulroney did not want to risk legitimizing the override clause by invoking it on the abortion issue, and his leadership stands as the most profound period of normative opposition to the override.

Despite the mega-constitutional and national unity issues that were a hallmark of the first two of Chrétien's three majority terms, the only occasion in which the notion of using the override power occurred in the case of RJR-MacDonald v. Canada (1995). The Supreme Court struck down legislation banning tobacco advertising, ruling that the tobacco companies' freedom of expression rights were unconstitutionally restricted. ${ }^{52}$ The Court's opinion was that the ban deprived both Big Tobacco and the consumer of disseminating and receiving information relating to the health risks and other considerations in tobacco usage. ${ }^{53}$ This was a case in which the public may have supported government action to limit the rights of a corporation that is responsible for numerous health risks and terminal diseases, yet Chrétien astutely chose to avoid the fray. Public opinion had turned solidly against the tobacco companies; as one advertising 
executive stated, “They'd [tobacco companies] have to be brain dead to thumb their noses at public opinion and the government." ${ }^{54}$ As it stands, the only advocate in Parliament this writer could find in support of using the override in this case was the NDP's Ed Broadbent and other members of that party. ${ }^{55}$

As the Chrétien years wore on into the new century, the movement towards legalizing same-sex marriage gained considerable momentum. In preventing the opposition parties from passing a bill that required the government to take “all necessary steps” to protect the traditional definition of marriage, Chrétien re-framed the debate into a referendum on the notwithstanding clause. His success in doing so, and in defeating the opposition bill, was seen as "indicative of a growing convention” that s.33 should never be used by any government. ${ }^{56}$ He viewed the Charter as a living and active document and did not want to preclude sexual orientation from any dialogue between Parliament and the Supreme Court, stating that it was an "open-ended” debate and for "the court to decide" whether sexual orientation should fall under s.15 of the Charter. ${ }^{57}$ Chrétien demonstrated that he had no intention of using s.33 in the same-sex marriage debate; his normative opposition to the notwithstanding clause was based on his belief that there should be dialogue between the legislative and judicial branches. ${ }^{58}$ By the 2000 election campaign, Chrétien had turned entirely against the override clause that he had once given a small vestige of support for including in the Charter. Referring to s.33 as "a nice way to destroy the Charter of Rights,” and expressing his pride that no federal government used the override, ${ }^{59}$ Chrétien laid the groundwork for the permanent opposition to the use of the override by the Liberals. Though his successor did broach the subject, advocacy of invoking the override has largely emanated from Conservatives, something which Liberals will pinpoint as emblematic of a "hidden agenda" of their electoral opponents.

Though he had signaled support for legalization of same-sex marriage, Chrétien was unable to pass a bill before leaving office and being succeeded by Paul Martin. This story is interwoven with that of Stephen Harper's attitude towards the notwithstanding clause, and thus both will be discussed here. During the course of the debate, both proponents and opponents of same-sex marriage broached the idea of the necessity to invoke the notwithstanding clause. Martin engaged both sides of the debate; it will be recalled that he had suggested using the override to affirm religious freedoms on the matter. In the end, he rejected both camps' overtures and avoided the use of s.33 to either affirm religious freedoms or override equality rights. Now 
that same-sex marriage has been legalized, it is "highly unlikely you're going to be able to reinstitute the opposite-sex definition of marriage without using the notwithstanding clause.”60

Paul Martin’s opposition to the notwithstanding clause did not appear to be based on the same normative attitude held by his predecessor, given his musing about using it during the debate. Political considerations played a larger part in his decision-making than the notwithstanding taboo, making him a unique case in this study. His idea of legislating s.33 out of Parliament was hastily concocted, and reportedly Martin never brought it up with the constitutional scholars in his Cabinet. ${ }^{61}$ During the election campaign, Harper pledged to not use the override to overturn C-38, a break from past stances, indicating that the political ramifications of the notwithstanding taboo have impacted his decision-making process. Thus there has been a convergence between ideals and political pragmatism among Canada's leaders which has made the use of the notwithstanding clause a taboo topic in contemporary Canadian political discourse.

\section{Conclusions: The Future of the Notwithstanding Clause}

When examining the historical record involving the federal government's non-use of the notwithstanding clause it is tempting to agree with Monahan’s contention that s.33 is “obsolete" in English Canada. Given that it has now been over fifteen years since Quebec last invoked the override, one could argue that it has now become a taboo in that province as well. There are profound arguments to be made against using the override either preemptively or in reaction visà-vis rulings from the judicial branch. Regarding preemption, Hiebert provides the best argument:

The override should not be used pre-emptively, to preclude judicial review, because this would circumvent conversation and deny the polity of the benefits of hearing the judiciary's concerns about the effects of the legislation for protected rights. ${ }^{62}$

On reaction, refer to Cotler's statement that to use the notwithstanding clause is to acknowledge that the government is violating rights of Canadians. ${ }^{63}$ Regardless of when, the invocation of s.33 by any government has substantial political consequences that will more than likely have negative effects on that government's hopes for re-election.

But does this truly indicate that $\mathrm{s.33}$ is a dead letter in Canadian politics? National security and public safety have trumped rights in the past, and the potential for a repeat of history certainly exists. Bill C-36, Canada’s counterterrorism legislation passed after 9/11, may yet clash 
with rights and freedoms. The enhancement of policy authority has a historical parallel in the War Measures Act, and concerns have arisen that judicial control over "search-and-seizure, arrest, and surveillance powers," all of which fall under the Charter umbrella in ss.7-14, may be insufficient to prevent abuses. ${ }^{64}$ A terrorist attack in Canada would almost certainly provoke enhanced state powers and possibly include a temporary suspension of civil liberties. If Trudeau, the champion of individual liberties, suspended rights, it is not beyond the scope of the possible that it could happen again.

Additionally, religious freedoms and minority groups demanding equality are two key challenges to the notwithstanding taboo. The decision in Multani (2006) establishes a conflict between a religious expression and public safety concerns. It would only take one incident of the ceremonial dagger being utilized in self-defence to provoke public outcry for the government to use s.33 to protect children. It thus, as Justice Charron stated, falls on schools to educate children to respect other groups and promote tolerance of the religious practices of Canada's minorities.

Tolerance and respect are at the heart of minority group rights, but often the majority, in conceding equality rights, does not give its approval and limits its expression to a "merely reluctant tolerance” of minority groups. ${ }^{65}$ As more and more groups demand the "unconditional surrender" of the majority to give their approval in granting rights, ${ }^{66}$ there will occasionally arise a backlash among the majority. Some will argue that society is "not ready" to grant approval of particular minority interests_-'swingers clubs’ and polygamist groups readily come to mindand there will be considerable pressure on governments to act preemptively to forestall any possibility of these claims for rights gaining acceptability. These claims must be evaluated on a case-by-case basis for their applicability to either Charter rights or the Criminal Code, and those which fall under the former could be restricted via the notwithstanding clause. ${ }^{67}$ It is difficult to predict a government's response to such hypothetical scenarios; a Conservative government would face immense pressure from its electoral base of support to use any means necessary to indefinitely ban polygamy. If it chose to use s.33, however, the Tories would arouse considerable outrage from those who view any use of the override as illegitimate, even if to outlaw practices that a majority of the population deems immoral.

The ultimate question thus remains: does a notwithstanding taboo exist and will it continue to deter governments from using s.33 to override Charter rights? Because the Charter is held to such lofty standards by Canadians, to a greater extent than the Bill of Rights, and because 
it provides "a living constitution for a liberal democratic state ... [recognizing] the equal human dignity of all members of Canadian society, ${ }^{, 68}$ governments must be extremely cautious in even publicly contemplating its use. For Ottawa to cross the Rubicon and actually use s.33 for any purpose, no matter how defensible, would signify a serious breach of trust and respect for the values of Canadians. No Prime Minister of Canada wants to be known as the first leader to deprive rights to a minority group in Canada or make illegal any action or expression that is protected by the Charter.

Thus, I respond to the above question in the affirmative. Norms "do not determine outcomes" and are confined to influencing "the probability of occurrence of certain courses of action." ${ }^{\prime 69}$ Yet to deny that there is an obstacle beyond realist electoral considerations seems inappropriate and overlooks the normative statements by leaders such as Mulroney and Trudeau, and academics such as Mandel (who, it will be recalled, described s.33 as "evil"). It is exceedingly difficult to predict the future in political science, but given elected officials' reluctance to wade into the murky waters of the notwithstanding debate and 25 years of historical non-use weighing on their minds as a political barrier, some measure of certainty can be exercised in stating that the state's ability to "pursue compelling legislation" to infringe rights ${ }^{70}$ may yet become truly "obsolete" in the same fashion as the federal Parliament's power of disallowance.

\footnotetext{
$\underline{\text { Notes }}$

${ }^{1}$ Janet Hiebert, "Parliament, Courts, and Rights: Sharing Responsibility for Interpreting the Charter," in James Bickerton and Alain-G. Gagnon, eds., Canadian Politics, $3^{\text {rd }}$ ed., (Peterborough, ON: Broadview Press, 1999), 185, 186.

${ }^{2}$ Peter W. Hogg and Allison A. Thornton, “The Charter Dialogue Between Courts and Legislatures,” Policy Options 20.3 (1999), 20.

${ }^{3}$ Peter W. Hogg, Constitutional Law of Canada, Student Edition 2002, (Toronto: Carswell, 2002), 820.

${ }^{4}$ As will be discussed below, Trudeau suspended the Bill of Rights in invoking the War Measures Act and subsequently used the Bill's override power to make it a criminal offence to be affiliated with the Front Liberation de Quebec, thereby curtailing freedom of association rights.

${ }^{5}$ Howard Leeson, "Section 33, The Notwithstanding Clause: A Paper Tiger?” IRPP Choices 6.4 (2000), 20.

${ }^{6}$ Nina Tannenwald, "The Nuclear Taboo: The United States and the Normative Basis of Nuclear Non-Use," International Organization 53.3 (1999), 433.

${ }^{7}$ This assessment is shared by Leeson, "Section 33," 19.

${ }^{8}$ Peter W. Hogg, "A Comparison of the Canadian Charter of Rights and Freedoms with the Canadian Bill of Rights," in Walter S. Tarnopolsky and Gerald-A. Beaudoin, eds., The Canadian Charter of Rights and FreedomsCommentary, (Toronto: Carswell, 1982), 11.
} 
${ }^{9}$ Herbert Marx, "Entrenchment, Limitations, and Non-Obstante (Ss. 1, 33, and 52), in Tarnopolsky and Beaudoin, eds., The Canadian Charter of Rights and Freedoms, 73.

${ }^{10}$ Tannenwald, "The Nuclear Taboo," 436.

${ }^{11}$ Benjamin J. Cohen, "Phoenix Risen: The Resurrection of Global Finance,” World Politics 48.2 (1996), 291.

${ }^{12}$ This at least applies as it pertains to same-sex marriages. Harper had pledged that he would not use s.33 to prevent same-sex couples from marrying, while Dion is the inheritor of the Trudeau-Chretien-Marin legacy of Liberal leaders opposed to the notwithstanding clause's invocation. Still, as Chantal Hebert notes, that Harper would even "ask the Commons to consider taking away the rights of a Canadian minority" is a matter of concern for some Canadians. Chantal Hebert, "Minority Rights Ugly Subtext in Same-Sex Debate,” Toronto Star 8 Dec. 2006. 2 Feb. 2007. <http://www.thestar.com/article/131493>

${ }^{13}$ Michael Ignatieff, The Rights Revolution, (Toronto: Anansi, 2004 (2000)), 2.

${ }^{14}$ Roy Romanow, "Courts and Legislatures in the Age of the Charter," Canadian Parliamentary Review 9.1 (1986), 2.

${ }^{15}$ Alan Cairns, “Citizenship and the New Constitutional Order," Canadian Parliamentary Review 15.3 (1992), 4.

${ }^{16}$ See <http://westernstandard.blogs.com/.shared/image.html?/photos/uncategorized/lapelpin.jpg>

${ }^{17}$ This remark was reportedly made on CBC Radio on 19 December 2003. Gudrun Schultz, "PM Martin Threatens Notwithstanding Clause, Ignores Promise to Protect Church Rights,” LifeSiteNews 10 Jan. 2006. 6 March 2006. $<$ http://www.lifesite.net/ldo/2006/jan/06011008.html>

${ }^{18}$ See his contribution chapter contribution to Tarnopolsky and Beaudoin, eds., The Canadian Charter of Rights and Freedoms, entitled "Freedom of Assembly, Association, Conscience, and Religion (s.2(a), (c), and (d)," pp. 123211.

19 “PM threatens election over same-sex marriage,” CTV 22 Jan. 2005. 6 March 2006.

<http://www.ctv.ca/servlet/ArticleNews/story/CTVNews/1106320326471_9/?hub=CTVNewsAt11>

${ }^{20}$ David Johansen and Philip Rosen, “The Notwithstanding Clause of the Charter (BP194e)," Library of Parliament. Feb. 1989 (Revised May 2005). 2 Feb. 2007. <http://www.parl.gc.ca/information/library/ PRBpubs/bp194-

e.htm\#Arguments>

${ }^{21}$ Phil Hahn, “Stephen Harper wins Conservative minority,” CTV 24 Jan. 2006. 20 March 2006.

$<$ http://www.ctv.ca/servlet/ArticleNews/story/CTVNews/20060123/elxn_main_story_060123/20060123?s_name=el ection2006>

${ }^{22}$ Hogg, Constitutional Law of Canada, 679.

${ }^{23}$ The entire contents of the Bill of Rights can be found at Department of Justice, Canadian Bill of Rights (1960). 2 March 2006. <http://laws.justice.gc.ca/en/c-12.3/28161.html>

${ }^{24}$ Canada, Bill of Rights (1960), s.1.1(a).

${ }^{25}$ Harper qualified that statement saying that this issue is not a "high priority." "Harper, Martin spar over property rights,” CBC 12 Jan. 2006. 2 March 2006. <http://www.cbc.ca/story/canadavotes2006/national/2006/01/12/elxnpropertyrights-harpmart.html>

${ }^{26}$ Hogg, Constitutional Law of Canada, 683.

${ }^{27}$ Gad Horowitz, "Conservatism, Liberalism, and Socialism in Canada: an Interpretation,” in Katherine Fierlbeck, ed., The Development of Political Thought in Canada: an Anthology, (Toronto: Broadview, 2005), 222.

${ }^{28}$ Ibid, 220, 222.

${ }^{29}$ Havi Echenberg, "Fifty Years of Social Policy: Playing ‘Hide and Seek’ with Heroes and Villains,” Policy Options 24.6 (2003), 47.

${ }^{30}$ Robert Bothwell, et al., Canada since 1945: Power, Politics, and Provincialism, (Toronto: University of Toronto Press, 1981), 202.

${ }^{31}$ Pierre Trudeau, “National Broadcast,” 16 Oct. 1970 Libraries and Archives Canada. 5 March 2006.

$<$ http://www.collectionscanada.ca/primeministers/h4-4065-e.html>

${ }^{32}$ Bayard Reesor, The Canadian Constitution in Historical Perspective with a Clause-by-Clause Analysis of the Constitution Acts and the Canada Act, (Scarborough, ON: Prentice-Hall, 1992), 69.

${ }^{33}$ Canada, Public Order (Temporary Measures) Act, 2 Nov. 1970, s.4.

${ }^{34}$ Cotler, "Assembly, Association, Conscience, and Religion," 167-68.

${ }^{35}$ Deborah Coyne and Michael Valpy, To Match a Dream: A Practical Guide to Canada's Constitution, (Toronto: McClelland \& Stewart, 1998), 141.

${ }^{36}$ Hogg, Constitutional Law of Canada, 68.

${ }^{37}$ Michael Ignatieff, The Lesser Evil: Political Ethics in an Age of Terror, (Toronto: Penguin, 2004), 2. 
${ }^{38}$ This statement, made by Peter Hogg, should be qualified; the Yukon Territory, which had included the override in a defeated bill, can argue it has never enacted s.33 and should be excluded from the category of override-using legislatures. Hogg, Constitutional Law of Canada, 814.

${ }^{39}$ Rory Leishman, "Martin proves inconsistent,” The Interim Sept. 2004. 7 March 2006.

$<$ http://www.theinterim.com/2004/sept/01martinproves.html>

${ }^{40}$ Roy Romanow et al., Canada...Notwithstanding: The Making of the Constitution 1976-1982, (Toronto: Carswell, 1984), 43-44.

${ }^{41}$ Leeson, "Section 33," 3-4.

${ }^{42}$ Romanow, "Courts and Legislatures in the Age of the Charter," 3.

${ }^{43}$ Alain Noel, "Is Decentralization Conservative? Federalism and the Contemporary Debate on the Canadian Welfare State," in Robert Young, ed., Stretching the Federation: The Art of the State in Canada, (Montreal \& Kingston: McGill-Queen’s University Press, 1999), 211.

44 "Ban on Sikh kirpan overturned by Supreme Court,” CBC News 2 March 2006. 10 March 2006.

<http://www.cbc.ca/story/canada/national/2006/03/02/kirpan-scoc060302.html>

${ }^{45}$ On a more limited basis, because the provinces are responsible for education, they would be the authority with the constitutional authority to invoke s.33 to ban the kirpan in schools. It could be argued that any such scenario as the one described would result in discussion of a more broadly-based ban than merely confining the debate to whether or not schools should permit their wearing, leaving considerable grey area as it pertains to which level of government would be compelled to take action.

46 Janice Tibbetts, “Dagger Ban Struck Down,” National Post 3 March 2006, A1.

${ }^{47}$ This belief is held by some despite the fact that there has never been an incident at a school involving the kirpan, which was cited as "overwhelming empirical evidence that the kirpan is not a dangerous weapon" by Multani's

defence team. Jim Brown, "School Ban on Sikh Daggers Not Justified, Says Supreme Court," 2 March 2006. 6 Feb. 2007. <http://www.canada.com/topics/news/national/story.html?id=a00800be-2427-4554-af67cf0135039b26\&k=93577>

${ }^{48}$ The so-called "caretaker convention" in Canadian parliamentary tradition explains that governments who lack full legitimacy, as was the case with Turner and Campbell because they were not given a mandate by the voters, should not engage in major decision-making. The Campbell example revolved around her decision in the Pearson Airport Agreements to lock the federal government into a 57-year leasing contract. John Wilson, "The Status of the Caretaker Convention in Canada," Canadian Parliamentary Review 18.4 (1995), 18.

${ }^{49}$ Leeson, "Section 33," 14.

${ }^{50}$ Mandel, The Charter of Rights and the Legalization of Politics in Canada, 82.

51 “Abortion Rights: a Timeline of Developments,” CBC News 16 June 2005. 11 March 2006.

$<$ http://www.cbc.ca/news/background/abortion>

${ }^{52}$ Leeson, "Section 33," 18-19.

53 “The Supreme Court Ruling on the Tobacco Products Control Act," Health Canada, Dec. 1995. 11 March 2006. $<$ http://www.hc-sc.gc.ca/ahc-asc/media/nr-cp/1995/1995_85bk2_e.html>

${ }^{54}$ Warren Caragata et al., “Tobacco Advertising Ban Unconstitutional,” Maclean’s 2 Oct. 1995. Article available online: http://www.thecanadianencyclopedia.com/index.cfm?PgNm=TCE\&Params= M1ARTM0010486

${ }^{55}$ Rainer Knopff and Andrew Banfield, “It's the Charter Stupid: Electoral Politics and the Supreme Court” Address to the Annual Meeting of the Canadian Political Science Association, London, ON, 2 June 2005. 28 March 2006.

$<$ http://www.cpsa-acsp.ca/papers-2005/Banfield.pdf> p.8.

${ }^{56}$ Christopher P. Manfredi, “Same-Sex Marriage and the Notwithstanding Clause,” Policy Options 24.9 (2003), 21.

${ }^{57}$ This statement actually was made in 1981 when Chrétien was pressed by MP Svend Robinson on same-sex rights under the Charter. Chrétien held remarkably consistent over the years on the issue. Graham Fraser, "What the Framers of the Charter Intended,” Policy Options 24.9 (2003), 18.

${ }^{58}$ See above, p.13, for Chretien and Trudeau's shared view on the override as a means of providing "flexibility" in debates between the two institutions of government.

${ }^{59}$ John Ward, “Social spending or tax cuts?” The Halifax Chronicle-Herald 31 Oct. 2000. 12 March 2006.

$<$ http://72.14.203.104/search?q=cache:ur2LiCHJxAwJ:www.herald.ns.ca/cgi-

bin/home/terrordisplaypackstory\%3F2000/10/31\%2B201.raw\%2BFE00Oct31\%2B2+\%22a+nice+way+to+destroy+ the+Charter+of+Rights\%22\&hl=en\&gl=ca\&ct=clnk\&cd=2>

60 “Experts say Harper’s strategy won’t work,” The Leader-Post (Regina), 17 Dec. 2005, D11. 11 March 2006.

<http://osgoode.yorku.ca/media2.nsf/83303ffe5af03ed585256ae6005379c9/15c173c677c9bbc98

52570dc00668b40!OpenDocument> I am not entirely convinced of this argument. If Parliament were to repeal C- 
38, there would have to be a new wave of Supreme Court challenges on existing laws that produce results which concretely state that same-sex couples' equality rights are violated by the traditional definition of marriage. This would be to essentially turn back the clock to 2004, where no such Court challenge had occurred at the federal level. ${ }^{61}$ Ann McLellan is herself a former professor in constitutional law, and she holds a normative opposition to s.33, denouncing the "political compromise" that brought s.33 into existence shortly after informing reporters that Martin never broached his idea with her. “'Glitches' dog McLellan,” The Edmonton Journal 18 Jan 2006. 11 March 2006. <http://www.canada.com/edmontonjournal/news/story.html?id=7e8a10c6-c495-4b85-bc27-f16544d84f1d\&p=1> ${ }^{62}$ Hiebert, "Parliament, Courts, and Rights,” 202.

${ }^{63}$ See above, p.8.

${ }^{64}$ Ignatieff, The Lesser Evil, 79-80.

${ }^{65}$ Ignatieff, The Rights Revolution, 87.

${ }^{66}$ Ibid, 17.

${ }^{67}$ The 'swingers clubs' decision made by the Supreme Court in R. v. Kouri (2005) was under the Criminal Code and thus not explicitly subject to $\mathrm{s} .33$ if the government wanted to act. In polygamy cases, certain religious groups which permit polygamy could be subjected to Charter-based judicial review.

${ }^{68}$ Weinrib, "The Activist Constitution," 29.

${ }^{69}$ Tannenwald, “The Nuclear Taboo,” 434-35.

${ }^{70}$ Hiebert, "Parliament, Courts, and Rights," 186. 